\title{
KUALITAS PELAYANAN FARMASI BERDASARKAN WAKTU PENYELESAIAN RESEP DI RUMAH SAKIT
}

\section{PHARMACY SERVICE QUALITY BASED ON TIME COMPLETION PRESCRIPTION IN HOSPITALS}

\author{
Nita Rusdiana, Rahayu Wijayanti, Sri Wahyuni \\ Sekolah Tinggi Farmasi Muhammadiyah Tangerang \\ Jl. Syeh Nawawi no $13 \mathrm{~km} \mathrm{4,} \mathrm{Tigaraksa,} \mathrm{Tangerang}$ \\ Email:nita.rusdiana270@gmail.com
}

Submitted : 13-08-2015

Reviewed : 15-08-2015

Accepted: 25-11-2015

\begin{abstract}
ABSTRAK
Berdasarkan Standar Pelayanan Kefarmasian Di Rumah Sakit, ada beberapa metoda yang diterapkan dalam mendistribusikan perbekalan farmasi di lingkungannya. Salah satu upaya pelayanan pasien rawat jalan adalah memperoleh obat yang diresepkan oleh dokter dalam waktu singkat. Tujuan dari penelitian ini adalah mengetahui kualitas pelayanan farmasi pasien rawat jalan yang diukur oleh waktu penyelesaian resep dokter di Instalasi Farmasi Rumah Sakit yang beradasar pada reliabilitas, daya tanggap, jaminan, empati, dan bukti fisik. Rancangan penelitian ini menggunakan metode crosssectional yang dilakukan selama bulan Januari-Februari 2015 yang kemudian dapat menganalisa kualitas pelayanan farmasi dan waktu penyelesaian resep di Instalasi Farmasi Rumah Sakit. Data yang digunakan dalam penelitian ini adalah data primer. Dalam penelitian ini menggunakan sampel sebanyak 157 responden untuk kuesioner dan 787 resep pasien rawat jalan. Hasil penelitian menunjukkan bahwa kepuasan tertinggi waktu penyelesaian adalah 13 menit. Untuk kelima variabel yang diujikan menunjukkan bahwa daya tanggap memiliki skor tertinggi yaitu 3,18 dan bukti fisik memiliki skor terendah yaitu 2,53. Kesimpulan dari penelitian ini adalah waktu penyelesaian resep dokter yang memberikan jaminan kepuasan adalah kurang dari 13 menit dan didukung dengan hasil kuesioner yang dinyatakan dalam hasil tertinggi pada variabel daya tanggap sebesar 3,29 yang setuju bahwa waktu tunggu obat tidak lama.
\end{abstract}

Kata kunci : waktu pelayanan, resep dokter, pasien rawat jalan

\section{ABSTRACT}

Based on Standard of Pharmaceutical Quality in Hospitals, there are methods are applied to distribute pharmaceuticals. One outpatient care efforts is to obtain medication prescribed by a doctor in a short time. The quality of outpatient pharmacy services as measured by the time of complete prescription at the pharmacy installation hospitals are based on reliability, responsiveness, assurance, empathy and tangibles. The study use cross-sectional's method, which is done by January-February in 2015 , to analyze pharmacy quality standard and time of complete prescription. The data used in this study are primary data. This study was used sample of 157 respondents for quetioners and 787 outpatients prescriptions. The results showed that the highest satisfaction turn around time is 13 minutes. For the five variables tested showed that the responsiveness had the highest scores of 3.18 and tangibles has the lowest score of 2,53. Conclusion, time of complete prescription less than 13 minutes and supported by quetioners shows the highest variables of responsiveness at 3,29 are agreed that time to wait is not too long.

Keywords: time services, prescription, outpatient 


\section{PENDAHULUAN}

Pemenuhan kebutuhan pasien akan obat dan informasi serta memberikan pelayanan yang memuaskan pada pasien rawat jalan adalah orientasi utama dalam pelayanan kefarmasian. Faktor penting untuk memenuhi kebutuhan perbekalan farmasi pasien rawat jalan adalah pendistribusian obat. Tujuan utama distribusi obat adalah tersedianya perbekalan farmasi di unit-unit pelayanan tepat waktu, tepat jenis dan tepat jumlah (Permenkes, 2014). Menurut Keputusan Menteri Kesehatan no 129 tahun 2008, standar minimal pelayanan rumah sakit memiliki indikator waktu tunggu pelayanan farmasi untuk obat jadi yaitu $\leq 30$ menit dan pelayanan farmasi untuk obat racik yaitu $\leq 60$ menit (Kepmenkes, 2008).

Model service quality merupakan acuan dalam riset pemasaran dalam hal pendekatan kualitas pelayanan jasa. Dalam pendekatan ini ditegaskan bahwa jika kinerja pada suatu atribut meningkat lebih besar daripada harapan atas atribut yang bersangkutan, maka kepuasan dan kualitas pelayanan pun akan meningkat, demikian pula sebaliknya. Pemenuhan kebutuhan sampai penilaian dari sudut pandang pelanggan menjadi patokan nilai suatu pelayanan terbaik berdasarkan profit strategy (Tjiptono dkk, 2011).

Dalam melakukan pelayanan, unit farmasi di setiap rumah sakit memiliki perencanaan, pengadaan, pendistribusian dan evaluasi yang tentunya dilakukan guna meningkatkan kualitas pelayanan farmasi dan guna mencapai tujuan yang telah ditargetkan, diantaranya meningkatkan mutu dan memperluas cakupan pelayanan farmasi di rumah sakit, memberikan pelayanan farmasi yang dapat menjamin efektifitas, keamanan dan efisiensi penggunaan obat, meningkatkan kerjasama dengan pasien dan profesi kesehatan lain yang terkait dalam pelayanan farmasi, serta melaksanakan kebijakan obat dirumah sakit dalam rangka meningkatkan penggunaan obat secara rasional (Pudjaningsih, 2006).

Pelayanan farmasi memiliki kualitas dan memberikan kepuasan kepada pasien, maka pihak rumah sakit harus memperhatikan berbagai dimensi yang dapat menciptakan dan meningkatkan kualitas pelayanan farmasinya. Lima dimensi kualitas pelayanan tersebut disusun sesuai urutan tingkat kepentingan relatifnya yaitu reliabilitas, daya tanggap, jaminan, empati, dan bukti fisik (Tjiptono dkk, 2011). Adapun tujuan dari penelitian ini adalah untuk mengetahui kualitas pelayanan farmasi rawat jalan yang diukur menggunakan waktu penyelesaian resep dokter di Instalasi Farmasi Rumah Sakit.

\section{METODE PENELITIAN}

1. Rancangan Penelitian

Penelitian ini menggunakan metode penelitian cross-sectional, yaitu suatu penelitian yang dilakukan dengan pengamatan sesaat atau dalam suatu periode tertentu dan setiap subyek studi hanya dilakukan satu kali pengamatan selama penelitian yang dilakukan pada periode JanuariFebruari 2015 untuk dapat menganalisa kualitas pelayanan farmasi dan waktu penyelesaian resep dokter di Instalasi Farmasi Rumah Sakit.

2. Populasi

Populasi penelitian adalah seluruh pasien rawat jalan di Rumah Sakit antara bulan JanuariFebruari 2015.

3. Menentukan Jumlah Sampel

Sampel ditentukan dengan cara random sampling dengan teknik accidental sampling, dimana peneliti hanya mengambil data berdasarkan responden yang datang pada saat dilakukan kegiatan secara langsung, karena pengambilan sampel di instalasi farmasi dilakukan pada saat shift pagi dengan waktu 8 jam per hari selama bulan Januari-Februari 2015. Peneliti menggunakan rumus levelconfidence sebagai berikut :

$$
\mathrm{n}=\frac{\mathrm{Z} \alpha^{2} \cdot \mathrm{P}(\mathrm{Q})}{\mathrm{e}^{2}}
$$

keterangan :

$$
\begin{array}{ll}
\mathrm{n} & =\text { jumlah sampel } \\
\mathrm{Z} \alpha & =\text { nilai dari level confidence } 90 \%(1.77370) \text { maka } \alpha=1-0,90=0,01 \\
\mathrm{P}(\mathrm{Q}) & =0,5 \\
\mathrm{e} & =\text { besar toleransi kesalahan } 10 \%(0,10)
\end{array}
$$




$$
\mathrm{n}=\frac{1,77370^{2} \times 0,5}{0,10^{2}}=\frac{1.57301}{0,01}=157,301 \rightarrow 157 \text { sampel responden }
$$

Jumlah sebaran kuesioner pada perhitungan diatas adalah untuk 157 sampel responden, sedangkan sampel data waktu penyelesaian resep dokter pasien rawat jalan sebanyak 787 resep yang diambil dari 40 resep pasien rawat jalan perhari selama bulan Januari-Februari 2015. Tujuan diambilnya keputusan menggunakan 40 resep pasien rawat jalan karena jumlah resep yang masuk ke instalasi farmasi per hari ada \pm 100 resep, dimana resep tersebut masih tercampur dengan resep pasien rawat inap dan resep pasien yang tidak terlayani akibat ketidaktersediaan obat di instalasi farmasi.

4. Alat dan Bahan Penelitian

Ada dua instrumen pengumpulan data yang dibutuhkan dalam penelitian ini, yaitu kualitas pelayanan menggunakan kuesioner dan waktu pelayanan resep menggunakan alat pencatat waktu (Time Stemp).

Bahan yang digunakan dalam penelitian ini adalah resep-resep pasien rawat jalan di instalasi farmasi yang berkaitan dengan kualitas pelayanan farmasi dan waktu pelayanan resep dokter.

5. Definisi Operasional Variabel

a. Variabel Kualitas Pelayanan Farmasi memiliki definisi sebagai kesesuaian antara harapan pasien dengan persepsi pasien atas pelayanan farmasi yang diberikan oleh pihak rumah sakit berdasarkan skor yang diukur berdasarkan dimensi sebagai berikut :

1) Reliabilitas (reliability), dengan indikator : ketepatan menepati janji, ketepatan waktu, kecepatan pelayanan, kesesuaian pelaksanaan, dan kejelasan informasi.

2) Daya Tanggap (Responsiveness), dengan indikator : kepedulian, kesediaan membantu, kesungguhan, ketepatan pelayanan, dan kesediaan menanggapi.

3) Jaminan (Assurance), dengan indikator: jaminan asuransi, kepercayaan, kesesuaian jam, rasa aman, dan kesopanan.

4) Empati (Empathy), dengan indikator : perhatian secara individual, jam operasi yang nyaman, pemahaman kebutuhan secara spesifik, membangun minat dan kenyamanan.

5) Bukti Fisik (Tangible), dengan indikator : fasilitas, jenis peralatan, kecanggihan peralatan dan kerapihan pegawai.

b. Variabel Waktu Penyelesaian Resep Dokter memiliki definisi sebagai waktu yang dihitung mulai saat pasien menyerahkan resep ke apotek diterima oleh apoteker sampai obat diserahkan kepada pasien sekaligus penjelasan informasi penggunaan obat.

6. Analisis Data

a. Uji Validitas dan Reliabilitas

Suatu kuesioner dikatakan valid jika pertanyaan pada kuesioner mampu untuk mengungkapkan sesuatu yang akan diukur oleh kuesioner tersebut. Uji validitas dapat dilakukan dengan menghitung korelasi antara data pada masing-masing pertanyaan dengan skor total, dengan menggunakan rumus teknik korelasi product moment (Umar, 2003), yaitu :

$$
r=\frac{n\left(\sum X Y\right)-\left(\sum X \sum Y\right)}{\sqrt{\left[n \sum X^{2}-\left(\sum X\right)^{2}\right]}\left[n \sum Y^{2}-\left(\sum Y\right)^{2}\right]}
$$

Keterangan :

$\mathrm{r}=$ koefisien korelasi

$\mathrm{n}=$ jumlah sampel

$\mathrm{X}=$ skor satu item pertanyaan

$\mathrm{Y}=$ jumlah skor item pertanyaan

Suatu kuesioner dikatakan reliabel atau handal, jika jawaban seseorang terhadap pertanyaan adalah konsisten atau stabil dari waktu ke waktu (Ghozali, 2005). Pada penelitian ini pengukuran hanya dilakukan satu kali saja dan kemudian hasilnya 
dibandingkan dengan pertanyaan lain atau mengukur korelasi antar jawaban pertanyaan. SPSS memberikan fasilitas untuk mengukur reliabilitas dengan uji statistik Cronbach alpha $(\alpha)$. Suatu variabel dikatakan reliabel jika memberikan nilai Cronbach alpha $(\alpha)>$ 0,60 .

b. Analisis Korelasi Sederhana

Koefisien korelasi sederhana menunjukkan seberapa besar hubungan yang terjadi antara dua variabel. Digunakan untuk mengetahui keeratan hubungan antara dua variabel dan mengetahui arah hubungan yang terjadi. Penelitian ini menggunakan SPSS dengan metode korelasi sederhana (bivariate correlation), yaitu Pearson correlation atau sering disebut product moment pearson. Nilai korelasi (r) berkisar antara 1 sampai -1, nilai semakin mendekati 1 atau -1 berarti hubungan antara dua variabel semakin kuat, sebaliknya nilai mendekati 0 berarti hubungan antara dua variabel semakin lemah (Sugiyono, 2010).

c. Analisis Regresi Sederhana

Analisis regresi linier sederhana merupakan metode analisa yang digunakan untuk mencari pengaruh atau mencari hubungan fungsional antara satu variabel independen terhadap variabel dependen dan sebaliknya. Adapun rumus yang digunakan disesuaikan dengan jumlah variabel yang diteliti (Hartono, 2004).

Keterangan:

$$
\mathbf{Y}=\mathbf{a}+\boldsymbol{\beta} \mathbf{X}
$$

$\mathrm{Y} \quad=$ variabel dependen

a $\quad=$ konstanta

$\beta=$ koefisien regresi linear

$\mathrm{X} \quad=$ variabel independen

\section{HASIL DAN PEMBAHASAN}

1. Hasil Uji Validitas dan Reliabilitas

Menguji kelayakan kuesioner menggunakan 30 responden untuk menjawab 24 pertanyaan kuesioner. Hasil validitas menunjukkan bahwa pertanyaan yang diajukan mampu mengukur apa yang ingin diteliti, sedangkan uji reliabilitas adalah mengukur konsistensi jawaban atas pertanyaan yang diulang.

Setelah dilakukan pengujian validitas, dapat dilihat pada nilai Cronbach's Item-Total Correlation $>$ nilai $r$ tabel. Nilai $r$ tabel dengan $n=24$ dan probabilitas $5 \%$ adalah 0,330 , sehingga dapat disimpulkan bahwa seluruh pertanyaan yang diajukan kepada responden valid digunakan untuk mengukur kualitas pelayanan. Tidak ada nilai baku secara statistik untuk menentukan kriteria reliabilitas dari alat ukur, namun beberapa praktisi berpendapat bahwa pernyataan dinyatakan relaibel jika memiliki Cronbach's Alpha> 0,7. Dapat dilihat dari nilai 0,927 yang menunjukkan bahwa 24 pertanyaan tersebut reliabel.

Berdasarkan data tabel II menunjukkan bahwa Responsiveness memiliki rata-rata paling menarik dari kelima variabel ukuran tingkat kepuasan pelanggan di instalasi farmasi rumah sakit. Dari 24 pertanyaan yang diajukan kepada responden, skor tertinggi sebesar 3,29 terdapat didalam lima atribut pertanyaan pada bagian Responsiveness, menyatakan bahwa responden setuju 64\% untuk pertanyaan "waktu menunggu obat tidak terlalu lama".

Dapat dilihat dari gambar 1, bahwa waktu penyelesaian resep dokter yang kurang dari 13 menit lebih memberikan jaminan kepada pasien untuk merasa puas dengan pelayanan kefarmasian.

2. Hubungan antara Waktu Penyelesaian Resep Dokter dengan Tingkat Kepuasan Pasien

Kualitas pelayanan dimulai dari kebutuhan hingga persepsi pasien. Kualitas pelayanan mempengaruhi kecepatan waktu pelayanan yang akan berpengaruh pula pada kepuasan pasien. Kepuasan pasien dalam penelitian ini diposisikan dengan lamanya waktu penyerahan resep masuk ke apotek sampai obat dan informasi penggunaan obat diterima oleh pasien. 
3. Hasil Deskriptif Tingkat Kepuasan Pelanggan

Respondenyang telah setuju terhadap pertanyaan-pertanyaan dalam kuesioner menunjukan hasil frekuensi, persentase, dan rataan skor jawaban yang dapat dilihat pada tabel III.

Pada tabel III, Nilai korelasi sebesar $-0,558$ dengan nilai probabilitas $(0,000)$ artinya terdapat hubungan signifikan antara waktu penyelesaian resep dokter dengan kepuasan pasien. Nilai korelasi $-0,558$ artinya semakin lama waktu penyelesaian resep dokter maka akan menurunkan kepuasan pasien.

Berdasarkan Tabel IV diperoleh persamaan sebagai berikut Kepuasan $=3,059-0,015$ Waktu. Interpretasi hasil persamaan regresi adalah jika lama penyelesaian resep dokter meningkat 1 menit maka akan menurunkan kepuasan pasien sebesar 0,015 satuan. Hal tersebut menjelaskan bahwa kepuasan pasien akan menurun nilainya di Instalasi farmasi jika semakin lama waktu penyelesaian resep dokter.

Tabel I. Uji Validitas dan Reliabilitas

\begin{tabular}{|c|c|c|c|c|c|c|c|}
\hline Variabel & Pertanyaan & $\begin{array}{c}\text { Corrected Item- } \\
\text { Total } \\
\text { Correlation } \\
\end{array}$ & $\begin{array}{c}\mathrm{r} \\
\text { tabel }\end{array}$ & Keterangan & $\begin{array}{c}\text { Cronbach's } \\
\text { Alpha }\end{array}$ & $\begin{array}{l}\text { Cut } \\
\text { Value }\end{array}$ & Keterangan \\
\hline \multirow[t]{5}{*}{ Reliability } & Q1 & 0.4987 & 0.361 & Valid & 0.8806 & 0.70 & Reliabel \\
\hline & Q2 & 0.7816 & 0.361 & Valid & 0.8688 & 0.70 & Reliabel \\
\hline & Q3 & 0.7622 & 0.361 & Valid & 0.8791 & 0.70 & Reliabel \\
\hline & Q4 & 0.6811 & 0.361 & Valid & 0.8814 & 0.70 & Reliabel \\
\hline & Q5 & 0.8135 & 0.361 & Valid & 0.8744 & 0.70 & Reliabel \\
\hline \multirow[t]{5}{*}{ Responsiveness } & Q6 & 0.6306 & 0.361 & Valid & 0.8803 & 0.70 & Reliabel \\
\hline & Q7 & 0.8532 & 0.361 & Valid & 0.8734 & 0.70 & Reliabel \\
\hline & Q8 & 0.8418 & 0.361 & Valid & 0.8751 & 0.70 & Reliabel \\
\hline & Q9 & 0.6398 & 0.361 & Valid & 0.8789 & 0.70 & Reliabel \\
\hline & Q10 & 0.7492 & 0.361 & Valid & 0.8781 & 0.70 & Reliabel \\
\hline \multirow[t]{5}{*}{ Assurance } & Q11 & 0.7568 & 0.361 & Valid & 0.8756 & 0.70 & Reliabel \\
\hline & Q12 & 0.7573 & 0.361 & Valid & 0.8792 & 0.70 & Reliabel \\
\hline & Q13 & 0.6074 & 0.361 & Valid & 0.8841 & 0.70 & Reliabel \\
\hline & Q14 & 0.7869 & 0.361 & Valid & 0.8809 & 0.70 & Reliabel \\
\hline & Q15 & 0.6271 & 0.361 & Valid & 0.8817 & 0.70 & Reliabel \\
\hline \multirow[t]{5}{*}{ empathy } & Q16 & 0.3859 & 0.361 & Valid & 0.8829 & 0.70 & Reliabel \\
\hline & Q17 & 0.6008 & 0.361 & Valid & 0.8755 & 0.70 & Reliabel \\
\hline & Q18 & 0.5261 & 0.361 & Valid & 0.8808 & 0.70 & Reliabel \\
\hline & Q19 & 0.7663 & 0.361 & Valid & 0.8738 & 0.70 & Reliabel \\
\hline & Q20 & 0.8061 & 0.361 & Valid & 0.8750 & 0.70 & Reliabel \\
\hline \multirow[t]{4}{*}{ Tangibles } & Q21 & 0.6914 & 0.361 & Valid & 0.8796 & 0.70 & Reliabel \\
\hline & Q22 & 0.7419 & 0.361 & Valid & 0.8905 & 0.70 & Reliabel \\
\hline & Q23 & 0.8376 & 0.361 & Valid & 0.8685 & 0.70 & Reliabel \\
\hline & Q24 & 0.8341 & 0.361 & Valid & 0.8755 & 0.70 & Reliabel \\
\hline
\end{tabular}


Tabel II. Hasil Deskripsi Jawaban Responden

\begin{tabular}{|c|c|c|c|c|c|c|c|c|c|c|c|}
\hline \multirow[t]{2}{*}{ Variabel } & \multirow[t]{2}{*}{ Pertanyaan } & \multicolumn{4}{|c|}{ Frekuensi } & \multicolumn{4}{|c|}{ Persen (\%) } & \multicolumn{2}{|c|}{ rata-rata } \\
\hline & & STS & TS & $\mathrm{S}$ & SS & STS & TS & $\mathrm{S}$ & SS & Pertanyaan & Variabel \\
\hline \multirow[t]{4}{*}{ Reliability } & $\begin{array}{l}\text { Q1 } \\
\text { Q2 }\end{array}$ & $\begin{array}{c}0 \\
28\end{array}$ & $\begin{array}{c}1 \\
109\end{array}$ & $\begin{array}{c}151 \\
43\end{array}$ & $\begin{array}{c}35 \\
7\end{array}$ & $\begin{array}{c}0 \% \\
15 \%\end{array}$ & $\begin{array}{c}1 \% \\
58 \%\end{array}$ & $\begin{array}{l}81 \% \\
23 \%\end{array}$ & $\begin{array}{c}19 \% \\
4 \%\end{array}$ & $\begin{array}{l}3.18 \\
2.16\end{array}$ & 2.86 \\
\hline & Q3 & 1 & 1 & 125 & 60 & $1 \%$ & $1 \%$ & $67 \%$ & $32 \%$ & 3.30 & \\
\hline & Q4 & 8 & 112 & 58 & 9 & $4 \%$ & $60 \%$ & $31 \%$ & $5 \%$ & 2.36 & \\
\hline & Q5 & 0 & 2 & 129 & 56 & $0 \%$ & $1 \%$ & $69 \%$ & $30 \%$ & 3.29 & \\
\hline \multirow{5}{*}{ Responsiveness } & Q6 & 1 & 5 & 119 & 62 & $1 \%$ & $3 \%$ & $64 \%$ & $33 \%$ & 3.29 & 3.18 \\
\hline & Q7 & 1 & 17 & 122 & 47 & $1 \%$ & $9 \%$ & $65 \%$ & $25 \%$ & 3.15 & \\
\hline & Q8 & 1 & 7 & 142 & 37 & $1 \%$ & $4 \%$ & $76 \%$ & $20 \%$ & 3.15 & \\
\hline & Q9 & 1 & 19 & 121 & 46 & $1 \%$ & $10 \%$ & $65 \%$ & $25 \%$ & 3.13 & \\
\hline & Q10 & 0 & 0 & 159 & 28 & $0 \%$ & $0 \%$ & $85 \%$ & $15 \%$ & 3.15 & \\
\hline \multirow[t]{5}{*}{ Assurance } & Q11 & 0 & 3 & 171 & 13 & $0 \%$ & $2 \%$ & $91 \%$ & $7 \%$ & 3.05 & 3.13 \\
\hline & Q12 & 0 & 2 & 135 & 50 & $0 \%$ & $1 \%$ & $72 \%$ & $27 \%$ & 3.26 & \\
\hline & Q13 & 1 & 4 & 160 & 22 & $1 \%$ & $2 \%$ & $86 \%$ & $12 \%$ & 3.09 & \\
\hline & Q14 & 0 & 1 & 163 & 23 & $0 \%$ & $1 \%$ & $87 \%$ & $12 \%$ & 3.12 & \\
\hline & Q15 & 0 & 3 & 151 & 33 & $0 \%$ & $2 \%$ & $81 \%$ & $18 \%$ & 3.16 & \\
\hline \multirow[t]{5}{*}{ Empathy } & Q16 & 0 & 2 & 147 & 38 & $0 \%$ & $1 \%$ & $79 \%$ & $20 \%$ & 3.19 & 2.83 \\
\hline & Q17 & 0 & 11 & 155 & 21 & $0 \%$ & $6 \%$ & $83 \%$ & $11 \%$ & 3.05 & \\
\hline & Q18 & 0 & 5 & 157 & 25 & $0 \%$ & $3 \%$ & $84 \%$ & $13 \%$ & 3.11 & \\
\hline & Q19 & 25 & 94 & 59 & 9 & $13 \%$ & $50 \%$ & $32 \%$ & $5 \%$ & 2.28 & \\
\hline & Q20 & 3 & 88 & 88 & 8 & $2 \%$ & $47 \%$ & $47 \%$ & $4 \%$ & 2.54 & \\
\hline \multirow[t]{4}{*}{ Tangibles } & Q21 & 7 & 34 & 103 & 43 & $4 \%$ & $18 \%$ & $55 \%$ & $23 \%$ & 2.97 & 2.53 \\
\hline & Q22 & 12 & 28 & 103 & 44 & $6 \%$ & $15 \%$ & $55 \%$ & $24 \%$ & 2.96 & \\
\hline & Q23 & 20 & 123 & 40 & 4 & $11 \%$ & $66 \%$ & $21 \%$ & $2 \%$ & 2.15 & \\
\hline & Q24 & 29 & 124 & 30 & 4 & $16 \%$ & $66 \%$ & $16 \%$ & $2 \%$ & 2.05 & \\
\hline
\end{tabular}

4. Hasil Kepuasan Tiap Waktu Penyelesaian Resep

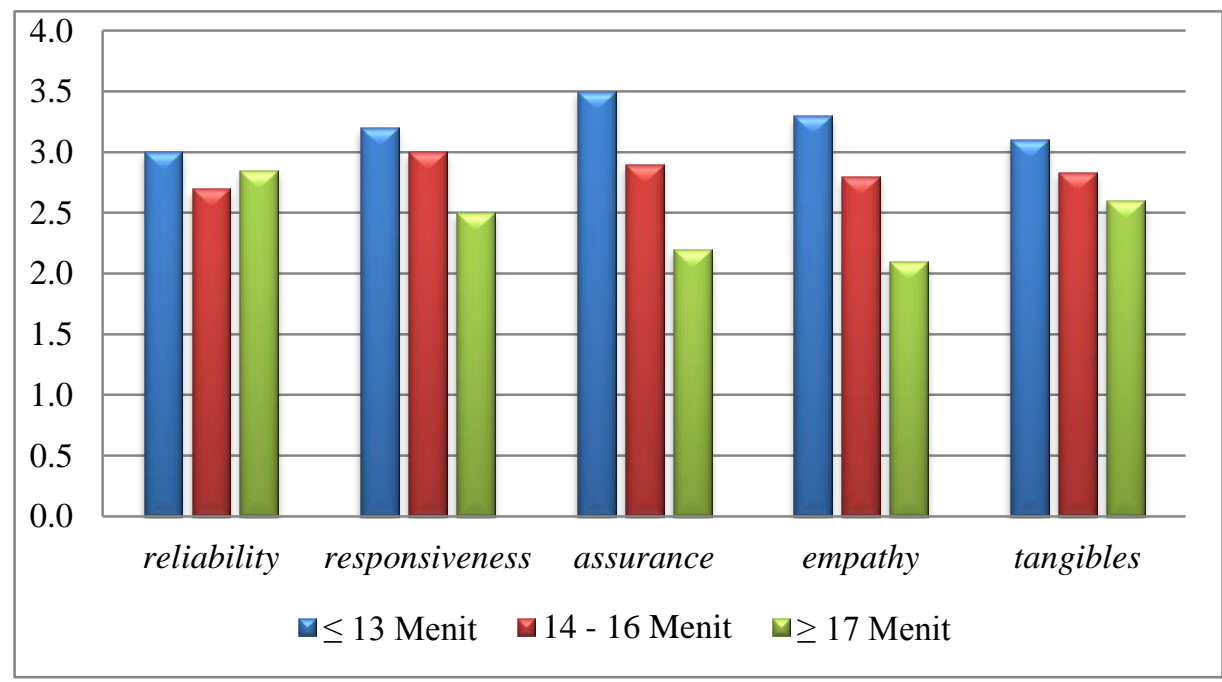

Gambar 1. Hasil Sebaran data Kepuasan 
Tabel III. Korelasi Waktu Penyelesaian resep dengan Kepuasan Pasien

\begin{tabular}{clrr}
\hline & Waktu & Kepuasan \\
\hline Waktu & Pearson Correlation & 1 &,$- 558^{* *}$ \\
& Sig. (2-tailed) & 65 &, 000 \\
& N &,$- 558^{* *}$ & 65 \\
Kepuasan & Pearson Correlation &, 000 & 1 \\
& Sig. (2 tailed) & 65 & 65 \\
& N & \\
& $* *$. Korelasi signifikan pada level 0,01 (2-tailed)
\end{tabular}

Tabel IV. Hasil Regresi Kepuasan Pasien dengan Waktu Penyelesaian Resep

\begin{tabular}{cccccc}
\hline \multirow{2}{*}{ Model } & \multicolumn{2}{c}{ Koefisien tak Terstandar } & $\begin{array}{c}\text { Koefisien } \\
\text { Terstandar }\end{array}$ \\
\cline { 2 - 6 } (Konstan) & $\mathrm{B}$ & Std. Error & Beta & $\mathrm{t}$ & Sig. \\
Waktu & 3,059 &, 049 & & 62,365 & 000 \\
\hline \multicolumn{7}{c}{, 015} &, 003 &,- 558 & $-5,335$ & 000 \\
\hline
\end{tabular}

Variabel dependen : kepuasan

\section{KESIMPULAN}

Bahwa, waktu penyelesaian resep dokter pada pasien rawat jalan yang paling memberikan jaminan kepuasan adalah kurang dari 13 menit berdasarkan variabel Assurance dan didukung dengan hasil kuesioner yang dinyatakan dalam skor tertinggi 3,29 yang setuju bahwa waktu tunggu obat tidak lama pada variabel Responsiveness. Semakin lama waktu menyelesaikan resep dokter akan menurunkan tingkat kepuasan pasien rawat jalan. Adapun saran yang dapat diberikan yaitu penambahan jumlah tenaga apoteker dan perluasan ruangan Instalasi Farmasi agar kepuasan pasien rawat jalan semakin meningkat.

\section{UCAPAN TERIMA KASIH}

Peneliti mengucapkan terimakasih kepada Allah SWT, keluarga dan seluruh civitas akademika di Sekolah Tinggi Farmasi Muhammadiyah Tangerang yang telah membantu dan mendukung selesainya tulisan ini.

\section{DAFTAR PUSTAKA}

Andriani, Susi dan Sunarto. 2009. Hubungan Kualitas Pelayanan Kesehatan dengan Kepuasan Pasien Rawat Inap di Badan Kesehatan Rumah Sakit Umum Daerah Kabupaten Magelang. JurnalKesehatan. Vol. 2, No 1. Hal 71-79

Arwani, Mukhlis dan Ernawati, Nina. 2013. Pengaruh Kualitas Pelayanan Fasilitas dan Harga Terhadap Kepuasan Pasien (Studi Kasus Pada RS PKU Muhammadiyah Gubug). JurnalQMan. Vol. 2, No. 2. Hal 1-16

Budiman, dkk. 2010. Hubungan Status Demografi dengan Kepuasan Masyarakat tentang Pelayanan Jamkesmas Wilayah Puskesmas Tanjungsari Kabupaten Bogor Tahun 2010. Jurnal Kesehatan Kartika. Hal 1-17

Firdian, Endy, dkk. 2012. Aplikasi Metode Servqual dan Six Sigma Dalam Menganalisis Kualitas Layanan PT. PLN (Persero) Unit Pelayanan Jaringan (UPJ) Dinoyo Malang. Jurnal Ilmu Pengetahuan \& Rekayasa. Vol. 13, No 3. Hal 51-61

Ghozali, Imam. 2005. Aplikasi Analisis Multivariat dengan Program SPSS. Semarang : UNDIP. Hal $41,45,84$

Hartono. 2004. Statistik Untuk Penelitian. Yogyakarta: Pustaka Pelajar Offset. Hal 140

Herjunianto, dkk. 2014. Faktor yang Mempengaruhi Cakupan Layanan Farmasi di Instalasi Rawat Jalan Rumah Sakit. Jurnal Kedokteran Brawijaya. Vol 28, No. 1. Hal 8-13 
Irmawati dan Kurniasari, Ria. 2010. Pengaruh Kualitas Pelayanan jasa Terhadap Keputusan Pasien Berobat Rawat Inap di RSUD Moewardi Jebres. Benefit : JurnalManajemendanBisnis. Vol. 15. No 1. Hal 1-16

Keputusan Menteri Kesehatan Nomor 129/Menkes/SK/II/2008 tentang Standar Minimal Pelayanan Rumah Sakit. Hal 12

Kotler, Philip. 1997. Manajemen Pemasaran, Jilid 1, Edisi Bahasa Indonesia. Diterjemahkan oleh : Hendra Teguh, dkk. Jakarta: Prenhallindo. Hal 36, 185

Peraturan Menteri Kesehatan Nomor 58 tahun 2014 tentang Standar Pelayananan Kefarmasian di Rumah Sakit.

Peraturan Pemerintah RI Nomor 51 Tahun 2009 tentang Pekerjaan Kefarmasian. Hal 2

Pudjaningsih, Dwi dan Santoso, Budiono. 2006. Pengembangan Indikator Efisiensi Pengelolaan Obat di Farmasi Rumah Sakit. Jurnal Logika. Vol. 3, No. 1. Hal 16-25

Simamora, Bilson. 2008. Panduan Riset Perilaku Konsumen. Jakarta: PT Gramedia Pustaka Utama. Hal 15

Suciati, Susi dan Adisasmito, Wiku B.B. 2006. Analisis Perencanaan Obat Berdasarkan ABC Indeks Kritis di Instalasi Farmasi. Jurnal Manajemen Pelayanan Kesehatan. Vol. 9 No 1. Hal 19-26

Sugiyono. 2010. Metode Penelitian Bisnis. Bandung : Alfabeta. Hal 59, 61, 199, 203, 391, dan 398.

Swarjana, I Ketut. 2012. Metodologi Penelitian Kesehatan: Tuntutan Praktis Pembuatan Proposal Penelitian. Yogyakarta: Andi Offset. Hal 135

Tjiptono, Fandy dan Chandra, Gregorius. 2011. Service, Quality \& Satisfaction. Edisi 3. Yogyakarta: Andi Offset. Hal 198,299,300

Wati, Wirdah, dkk. 2013. Evaluasi Pengelolaan Obat dan Strategi Perbaikan dengan Metode Hanlon di Instalasi Farmasi Rumah Sakit Umum Daerah Karel Sadsuitubun Kabupaten Maluku Tenggara tahun 2012. Prosiding Seminar Nasional Perkembangan Terkini Sains Farmasi dan Klinik III 2013. Hal 247-257 